\title{
First data on Myxomycetes of the State Nature Preserve "Sut-Khol", Republic of Tuva (Tyva), Russia
}

\author{
Anastasia Vlasenko ${ }^{1, *}$, Rada Shanmak ${ }^{2}$, Choigan Sambyla ${ }^{2}$ \\ ${ }^{1}$ Central Siberian Botanical Garden SB RAS, 630090 Novosibirsk, Russia \\ ${ }^{2}$ State Budgetary Institution “Tuvan Scientific Center”, 667000 Kyzyl, Tuva.
}

\begin{abstract}
First records of Myxomycetes from the Republic of Tuva, Russia, are presented. We identified 24 species of myxomycetes from 12 genera, 7 families and 4 orders in the State Natural Customer "Sut-Khol". For the Republic of Tuva, 14 species of myxomycetes have been identified for the first time. Arcyria globosa, first identified on the bark of a live Caragana in the Asian part of Russia using the "moist chamber". We have also identified a rare species of Echinostelium fragile on the bark of a live Pinus sylvestris.
\end{abstract}

\section{Introduction}

Myxomycetes are fungus like protists with a unique life cycle that includes vegetative (trophic) and generative stages. The vegetative phase of the life cycle is represented by multinucleated plasmodium, mononuclear amebes or zoospores. Zoospores and amebes are two forms of the same stage, and the transition process occurs when the humidity of the environment changes. The fruit bodies of myxomycetes (sporangia, plasmodiocarps, etalia, pseudoethalia) look very similar to the miniature fruit bodies of fungi.

Myxomycetes are found in all terrestrial biomes where there are living plants or dead plant debris. In forests, myxomycetes inhabit large woody substrates - fallen tree trunks, stumps, fallen branches, coniferous and deciduous litter, bark of living woody plants, old fallen cones of coniferous trees, stems and leaves of herbaceous plants. In the steppes and deserts, the growth of myxomycetes is confined to periods of intense rains. Myxomycetes of arid biotopes are identified in laboratory conditions by the method of wet chambers, growing them on natural substrates containing cysts and sclerotia. The lower parts of perennial dwarf shrubs, grass litter, and herbivorous animal dung are used as substrates.

A little more than 1000 species of myxomycetes have now been identified in the world. About 455 species of myxomycetes are currently known in Russia [1].

\footnotetext{
*Corresponding author: anastasiamix81@mail.ru
} 
The flora of higher plants and vegetation of the Republic of Tyva has been studied quite well [2-4], in contrast to myxomycetes. The study of myxomycetes of the Republic of Tuva was first started by us in 2020 .

\section{Materials and methods}

In 2021, a study of myxomycetes was carried out in the State Natural Customer "SutKhol". The Natural Customer is located in the spurs of the Western Sayan, in the central part of the Sut-Khol kozhuun. On the studied territory the sporophores of myxomycetes were collected and substrates were selected for growing of myxomycetes in "moist chambers".

Species identification was carried out using a Stemi DV4 stereo microscope, Axiolab Ere and Zeiss Axio Imager A1 light microscopes (Carl Zeiss Microscopy, Germany) in CSBG SB RAS. For microscopy, sporocarps were preserved as permanent slides in polyvinyl lactophenol.

Herbarium specimens were deposited into M.G. Popov Herbarium (NSK), Novosibirsk. The nomenclature of myxomycetes follows Lado [5].

\section{Results and Discussion}

We identified 24 species of myxomycetes from 12 genera, 7 families, and 4 orders. Below is an annotated list of species, indicating the species of myxomycetes, habitats, substrates and herbarium numbers. The species of myxomycetes, first identified in the Republic of Tyva, are marked «*», new for Asian part of Russia - «**», records of other species have been published by us previously [6].

\section{Lichen-dryad tundra}

*Didymium melanospermum (Pers.) T. Macbr., litter, NSK 1030931, 1030899.

*Echinostelium fragile Nann.-Bremek., bark of live P. sylvestris, NSK 1031011.

Hemitrichia serpula (Scop.) Rostaf. ex Lister, bark of live P. sylvestris, litter, NSK 1030198, 1030199, 1030201, 1030202.

Perichaena corticalis (Batsch) Rostaf., litter, NSK 1030170.

Stemonaria irregularis (Rex) Nann.-Bremek., R. Sharma et Y. Yamam., litter, NSK 1030159.

\section{Shrub-sedge boggy tundra}

**Arcyria globosa Schwein., bark of dried Artemisia, bark of live Caragana, NSK 1030860, 1030897, 1030920.

*Comatricha nigra (Pers ex J.F. Gmel.) J. Schröt., litter under Carex, NSK 1030923.

Didymium difforme (Pers.) Gray, bark of live Caragana, NSK 1030186, 1030189, 1030190.

Didymium ochroideum G. Lister, litter under Carex, NSK 1030153, 1030186.

Hemitrichia serpula (Scop.) Rostaf. ex Lister, litter under Carex, NSK 1030178, 1030179, 1030180, 1030942.

Perichaena corticalis (Batsch) Rostaf., bark of dried Artemisia, NSK 1030182.

*Physarum bivalve Pers., bark of dried Artemisia, NSK 1030860.

Physarum decipiens M. A. Curtis, bark of live Caragana, NSK 1030165.

Lichen-moss-lingonberry tundra with an admixture of larch and pine

Arcyria cinerea Bull. Pers., dead wood of burnt Larix, litter under larch with ground lichens, NSK 1030171, 1030948.

*Calomyxa metallica (Berk.) Nieuwl., fallen trunk of Larix, NSK 1030934. 

1030985 .

*Comatricha nigra (Pers ex J.F. Gmel.) J. Schröt., fallen trunk of Larix, NSK

Didymium squamulosum (Alb. et Schwein.) Fr., litter under Carex, mixed litter, NSK 1030173, 1030988.

Perichaena corticalis (Batsch) Rostaf., fallen trunk of Larix, NSK 1030181, 1030193, 1030204.

Perichaena depressa Lib., fallen trunk of Larix, bark of live Larix, NSK 1030156, 1030196, 1030197, 1030205, 1030210. 1030164.

Physarum gyrosum Rostaf., litter under Larix, NSK 1030161, 1030162, 1030163,

*Trichia lutescens (Lister) Lister, fallen trunk of Larix, NSK 1031003.

*Trichia varia (Pers. ex J. F. Gmel.) Pers., fallen trunk of Larix, NSK 1031129.

Yernik (bushy) tundra with sparse larch forest

*Arcyria pomiformis (Leers) Rostaf., fallen trunk of Larix, NSK 1030894.

*Enerthenema papillatum (Pers.) Rostaf., bark of live Larix, NSK 1030906.

*Paradiacheopsis fimbriata (G. Lister et Cran) Hertel ex Nann.-Bremek., bark of live Larix, NSK 1030935, 1031090.

Perichaena corticalis (Batsch) Rostaf., bark of live Larix, NSK 1030203.

Perichaena depressa Lib., bark of live Larix, NSK 1030167.

*Trichia decipiens (Pers.) T. Macbr. bark of live Larix, NSK 1030842, 1030889, 1031138.

Larch woodlands with shrub-moss cover

*Comatricha nigra (Pers ex J.F. Gmel.) J. Schröt., bark of live Larix, NSK 1030955. 1030177.

Didymium squamulosum (Alb. et Schwein.) Fr., fallen trunk of Larix, NSK

*Echinostelium minutum de Bary, bark of live Larix, fallen trunk of Larix, NSK 1030856, 1030904.

*Paradiacheopsis fimbriata (G. Lister et Cran) Hertel ex Nann.-Bremek., fallen trunk of Larix, NSK 1030939.

Perichaena depressa Lib., fallen trunk of Larix, NSK 1030183, 1030195.

*Trichia affinis de Bary in Fuckel, fallen trunk of Larix, NSK 1030871, 1030913.

\section{Conclusions}

As a result of the studies carried out for the Republic of Tuva, 14 new species of myxomycetes were identified, one of which - Arcyria globosa (Fig. 1. A.), first identified in the Asian part of Russia. Previously, A. globosa was identified in eight regions in the European part of Russia [7].

A rare species of myxomycetes, Echinostelium fragile, was identified on the bark of a living pine by the method of "moist chambers » (Fig. 1. B). Previously, this species was identified in five regions of Russia, including the European part [8], in Eastern Siberia [9], we also identified it earlier in Western Siberia in the Altai Territory, the Republic of Altai, and the Novosibirsk Region [10-12]. We will continue the study of myxomycetes in the Republic of Tuva, as it makes a significant contribution to understanding the distribution patterns and ecology of myxomycetes in Inner Asia. 


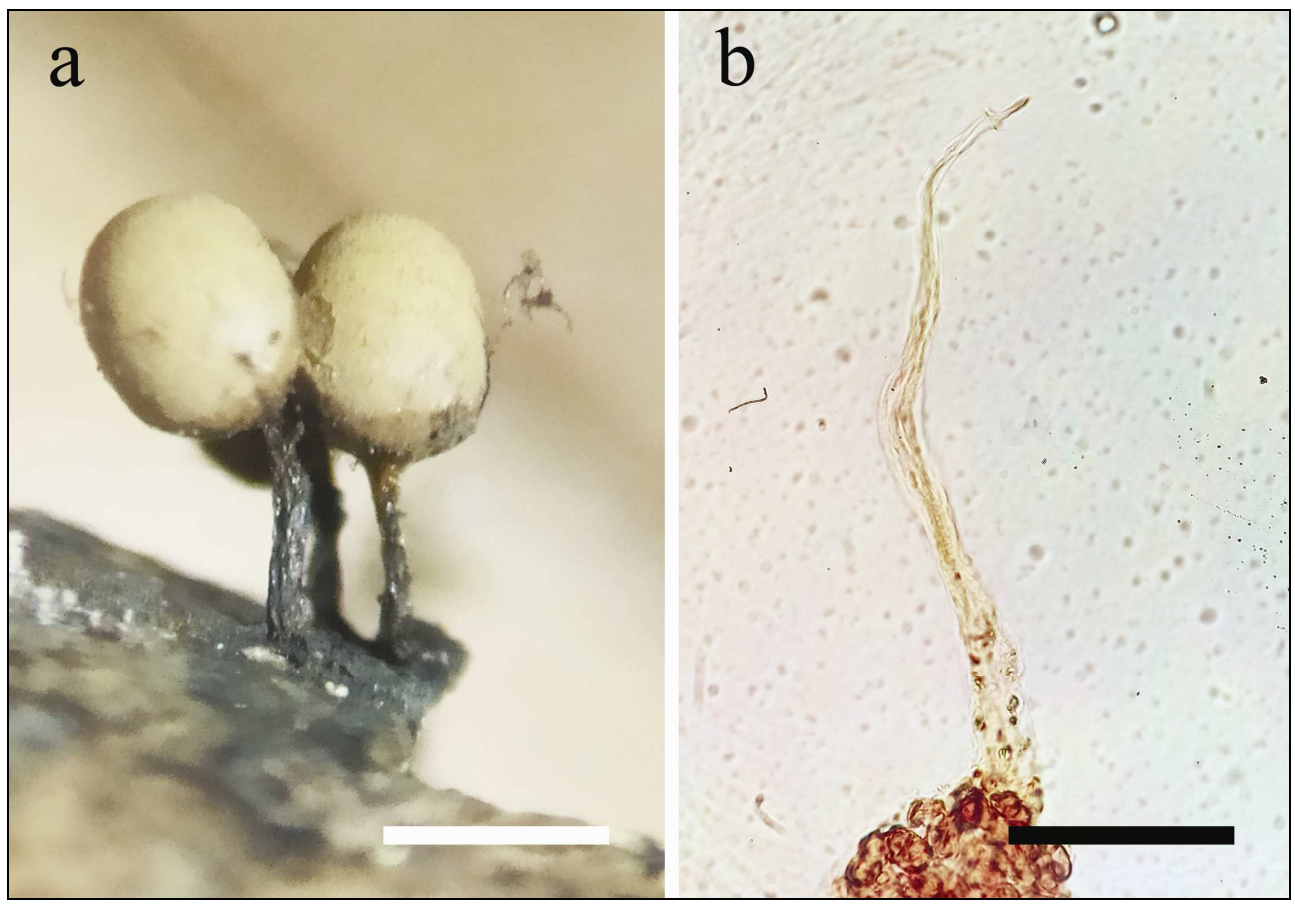

Fig. 1. A - Sporangia of Arcyria globosa grown in Petri dishes. B - Sporangia of Echinostelium fragile grown in Petri dishes. Bars: A $-0.5 \mathrm{~mm}, \mathrm{~B}-30 \mu \mathrm{m}$.

Acknowledgements. The research of V.A. Vlasenko and A.V. Vlasenko was carried out as a part of the State Task for the Central Siberian Botanical Garden, the Siberian Branch of the Russian Academy of Sciences, project AAAA-A21-121011290024-5. The all authors express their profound gratitude to the staff of the State Budgetary Institution "Tuvan Scientific Center" of the Ministry of Education and Science of the Republic of Tuva for organizing and conducting comprehensive research on the territory of the state natural customer "Sut-Kholsky". The work was partially carried out with the financial support of the research work "Provision of services for environmental assessment of the state of specially protected natural territories of regional significance of the Republic of Tuva", the state program of the Republic of Tuva and environmental protection for the period 2015-2020 and the Ministry of Natural Resources and Ecology of the Republic of Tuva.

\section{References}

1. F. M. Bortnikov, A. V. Matveev, V. I. Gmoshinskiy, Yu. K. Novozhilov, I. V. Zemlyanskaya, A. V. Vlasenko, M. Schnittler, O. N. Shchepin, N. A. Fedorova, Karstenia, 58, 2 (2020)

2. Ch. N. Sambyla, Sibirsk. Ecol. J., 14, 2 (2007)

3. E. G. Zibzeev, Ch. N. Sambyla, Plant resources, 43, 1 (2007)

4. R. Yu. Dudko, Ch. N. Sambyla, Evras. Entomol. J., 4, 3 (2005)

5. C. Lado. An online nomenclatural information system of Eumycetozoa. Real Jardín Botánico, CSIC. Madrid, Spain. Available from: http://www.nomen.eumycetozoa.com. Accessed 2021 May 31 (2005-2021)

6. A. V. Vlasenko, T. A. Ankova, The first data on myxomycetes of the Republic of Tyva and further research prospects, in Proceedings of the Ubsunur International Symposium, 5-8 July 2020, Kyzyl (2020) 
7. A. V. Matveev, F. M. Bortnikov, V. I. Gmoshinsky, Yu. K. Novozhilov. Myxomycetes of Russia. Available from: https://myxomycetes.org/russia. Accessed 2021 May 31 (2016-2021)

8. I. V. Zemlyanskaya, Yu. A. Smolnyakova, D. A. Kotelnikova, Yu. K. Novozhilov, Mycology and Phytopathology, 50 (2016)

9. A. P. Kosheleva, Yu. K. Novozhilov, M. Schnittler, Fung. Div., 31 (2008)

10. Yu. K. Novozhilov, M. Schnittler, A. V. Vlasenko, K. A. Fefelov, Mycotaxon, 111 (2010)

11. A. V. Vlasenko, V. A. Vlasenko, Samara J. Science, 6 (2017)

12. A. V. Vlasenko, Yu. K. Novozhilov, O. N. Shchepin, V. A. Vlasenko, Mycology and Phytopathology, 50 (2016) 